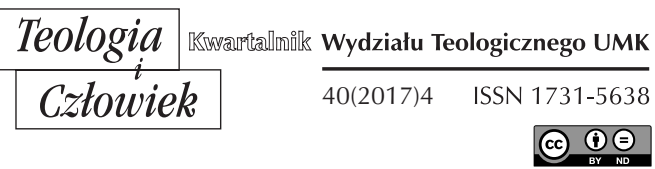

HALINA GWIŹDZIEL*

SYCÓW

\title{
SCHYŁEK FEMINIZMU RADYKALNEGO - WZROST ZNACZENIA RUCHÓW PRO-LIFE NA TLE WSPÓŁCZESNEJ SYTUACJI MIĘDZYNARODOWEJ
}

DOI: http://dx.doi.org/10.12775/TiCz.2017.051

\section{WPROWADZENIE}

Feminizm (łac. femina - kobieta) od chwili powstania do czasów obecnych przechodził pewne przeobrażenia, różnie go definiowano. Termin ten $\mathrm{w}$ wydaniu słownikowym pojawił się po raz pierwszy w roku 1933. Został on zdefiniowany jako ochrona praw kobiet, poprawa ich sytuacji społecznej i zrównanie w prawach z mężczyznami. Współcześnie pojęcie to jest stosowane na określenie różnorodnych ideologii, ruchów i działań społecznych, koncepcji teoretycznych, których przedmiotem są warunki oraz pozycja kobiet w zbiorowisku ludzkim ${ }^{1}$.

Rozpatrując ruch feministyczny w odniesieniu historycznym, daje się zauważyć trzy jego umowne fale: 1) przełom XIX i XX wieku; 2) lata

* Halina Gwiździel - mgr matematyki, teologii nauczyciel SP2 w Sycowie (halina59@vp.pl).

1 A. Titkow, Feminizm, w: Encyklopedia socjologii, red. Z. Bokszański, Warszawa 1998, s. 213. 
60. i 70. XX wieku; 3) połowa lat 90. XX wieku. W tym ostatnim pojawił się tak zwany feminizm radykalny (oprócz liberalnego i socjalistycznego). Współczesny feminizm radykalny w swojej strukturze ma odłamy kulturowe oraz lesbijskie. Feminizm ten zajmuje się zagadnieniami życia osobistego, seksualnością, cielesnością, walką z Kościołem. Feministki radykalne popierają aborcję, eutanazję, gender. Pragną zniszczyć tradycyjne role płciowe $\mathrm{w}$ małżeństwie i rodzinie. Walczą z wizją chrześcijańską rodziny, z życiem poczętym.

Kościół niezmiennie, od chwili ustanowienia go przez Jezusa Chrystusa, głosi nienaruszalność życia ludzkiego. Niezależnie od dyskusji naukowych, Kościół zawsze nauczał i nadal naucza, że owoc ludzkiej prokreacji od pierwszego momentu swego istnienia ma prawo do życia - od poczęcia do naturalnej śmierci. Życie ludzkie jest święte, gdyż tylko Bóg jest Panem życia i śmierci. Nauczanie Kościoła w tym względzie było i jest podważane, najczęściej przez ruchy lewicowe, w które włączają się środki masowego komunikowania.

Tymczasem we współczesnym świecie daje się zaobserwować osłabienie sił socjaldemokratycznych, które są powiązane $\mathrm{z}$ feminizmem radykalnym. W roku 2010 na Węgrzech władzę przejął Fidesz, a premierem został Viktor Orban. Podobne przemiany dokonały się w Polsce oraz w Stanach Zjednoczonych. Rządzący zaczęli zwracać uwagę na konieczność powrotu całych ludzkich społeczności do chrześcijaństwa, do respektowania społecznej nauki Kościoła. Na tym tle daje się zauważyć powrót ruchów pro-life (za życiem), które z wielką odwagą i determinacją bronią życia poczętego. Można zauważyć, iż dotąd krzykliwy i hałaśliwy radykalny feminizm wchodzi w okres schyłkowy.

Celem niniejszego artykułu jest ukazanie problemu aborcji na tle feminizmu radykalnego, który współcześnie boryka się z obroną głoszonych treści. Ponadto daje się zauważyć coraz bardziej powszechny brak akceptacji aborcji wśród ludzi młodych, dla których wielkimi wartościami jest miłość, małżeństwo i rodzina. Proaborcyjne manifestacje, aczkolwiek liczne i widowiskowe, wyraźnie słabną, a ruchy w obronie życia rosną w siłę. Ten trend wydaje się nie do zatrzymania. W niniejszym artykule podejmie się próbę zdiagnozowania tej sytuacji w odniesieniu do szybkich i dynamicznych przemian życia społecznego, politycznego, gospodarczego i kulturowego świata. Całość tych refleksji będzie miała odniesienie do Objawienia. 


\section{GENEZA FEMINIZMU. FEMINIZM RADYKALNY}

Od najdawniejszych czasów patriarchat był jedyną dominującą formą społeczną, która przyjmowała najróżniejsze kształty, struktury, konfiguracje. Kobiety były traktowane różnie, ale zawsze poddane były woli mężczyzn; wpierw władzy ojca, a później męża. Wdowieństwo oznaczało najczęściej opiekę brata, syna, zięcia.

Biorąc pod uwagę uwarunkowania życia społecznego w czasach najdawniejszych, a abstrahując od współczesności, można przyjąć pewne przyczyny tego stanu poddaństwa kobiet woli mężczyzn. Na plan pierwszy wysuwa się siła fizyczna mężczyzny, która mogła zawsze przerodzić się w brutalną przemoc. Kolejnym determinantem jest fizjologiczne obarczenie kobiety przez ciążę, porody, karmienie i opiekę nad dziećmi. Wiązało się to niejako z przywiązaniem jej do domu i uzależnieniem od mężczyzny. W tym czasie mężczyzna zdobywał pożywienie i bronił swojej rodziny przed niebezpieczeństwem; te fizyczne uwarunkowania predysponowały go do takiej właśnie roli, dodatkowo predestynując do uzewnętrzniania swojej władzy. Warto podkreślić, iż u mężczyzn występuje instynkt ojcowski, który powoduje, że stara się on zostać ojcem, między innymi poprzez uniezależnienie od siebie kobiety, która w pewnym sensie powinna stać się jego „własnością”. Mężczyźni od zawsze uniemożliwiali swobodę seksualną swoich kobiet, nawet siłowo².

W tym kontekście można zauważyć, iż instytucja matriarchatu byłaby raczej nieprawdopodobna i niemożliwa. Żaden mężczyzna nie zgodziłby się na utrzymywanie licznych dzieci, których nie jest ojcem, nie zgodziłby się na utrzymywanie kontaktów seksualnych swojej żony $\mathrm{z}$ innymi mężczyznami. Zapewne dlatego historia relacji mężczyzny z kobietą i całych społeczeństw potoczyła się właśnie w ten sposób.

W kolejnych epokach historycznych, aż do czasów współczesnych, mężczyzna rządzi, walczy, przetwarza świat, budując nowe cywilizacje. Patriarchat jest formą powszechnie obowiązującą. Natomiast kobieta poddana jest mężczyźnie, rodzi i wychowuje dzieci, opiekuje się domem, wykonuje konieczne prace, na ogół lżejsze, w gospodarstwie domowym. Najczęściej kobiety były traktowane jako niższe, pozbawione wszelkich

${ }^{2}$ K. Wiśniewska-Roszkowska, Feminizm zreformowany, Wrocław 1993, s. 8. 
praw, poddane bezwzględnej władzy mężczyzn. W tym czasie człowieczeństwo, godność osobowa i inne istotne wartości wiązały się wyłącznie z męskością.

Warto podkreślić, iż chrześcijaństwo odegrało ważną rolę w ukazaniu prawdziwych wartości osoby ludzkiej - kobiety i mężczyzny stworzonych na obraz i podobieństwo Boże (zob. Rdz 1,27). Jezus Chrystus wyraźnie i jednoznacznie wskazuje na równość płci, na konieczność uszanowania godności osób, na miłość, która powinna stać się dominującą siłą w relacjach międzyludzkich. Jezus Chrystus uczył, a za nim Kościół, że kobiecie należy się szacunek, poważanie, estyma. Oboje są przeznaczeni do nieba.

W okresie od XVII do XIX wieku w Europie wiara religijna słabnie, coraz silniejsze są ruchy emancypacyjne, czyli wyzwalanie się kobiet spod władzy mężczyzn, uzyskanie praw wyborczych. Do połowy XIX wieku ruch ten osiągnął centralny wymiar; kobiety po raz pierwszy w dziejach świata uzyskały swobody polityczne, wyborcze, jakie dotąd posiadali jedynie mężczyźni. Druga fala ruchu feministycznego miała miejsce w latach 60. i 70. XX wieku. Do jej powstania przyczyniła się przede wszystkim amerykańska organizacja National Organization of Women; jej celem było wprowadzenie kobiet do głównego nurtu życia Ameryki. Etap ten wypromował kolejne kwestie, które kobiety uznały za bardzo ważne, a w tym: dostęp do antykoncepcji; prawo do aborcji; powszechność kształcenia (na wszystkich uczelniach); zniesienie segregacji płciowej i zawodowej; odmitologizowanie roli matki i żony; odmitologizowanie męskości; równe traktowanie związków homo- i heteroseksualnych. Druga fala feminizmu to zerwanie $\mathrm{z}$ wizerunkiem kobiety pasywnej, zależnej ekonomicznie i emocjonalnie od mężczyzny. Klasyczny model rodziny został zakwestionowany i zdezawuowany ${ }^{3}$. Warto podkreślić, iż niektóre postulaty kobiet na tym etapie były słuszne, logiczne i racjonalne, jak chociażby powszechny dostęp do edukacji, zniesienie segregacji płciowej i zawodowej. Kobiety mają prawo do nauki, podjęcia pracy w wybranym zawodzie.

Trzecia fala feminizmu rozpoczęła się (umownie) w latach 80. XX wieku i trwa nadal. Jest to pewnego rodzaju odpowiedź na drugą falę, któ-

3 J.P. Mroczkowska, Nowy feminizm amerykański, „Znak” 8 (1995), s. 97. 
ra nie przyniosła spodziewanych rezultatów. Obecnie feministki zwracają uwagę na wiele nowych problemów, które dotykają sfer życia: społecznego, politycznego, kulturalnego, obyczajowego, religijnego, etnicznego, ekonomicznego. Znamienny jest fakt, iż kobiety mają już świadomość równości z mężczyznami w wielu dziedzinach życia. Chcą teraz walczyć o zrównanie w prawach nie tyle w państwach demokratycznych, co w tych krajach, w których panuje ustrój patriarchalny (w rodzinie rządzi ojciec, mężczyzna $)^{4}$. Feministki nie pragną obecnie przemawiać tłumnie; one chcą wspomagać kobiety, które są traktowane drugorzędnie, a szczególnie w krajach, do których jeszcze nie dotarła demokracja, wyzwolenie, równouprawnienie. Zatem jest to feminizm ogarniający niemal cały ziemski glob i jego zasady są słuszne ${ }^{5}$.

Feministki nadal poszukują własnej tożsamości, podejmują pogłębione refleksje nad relacjami z mężczyznami oraz propagują czasami niczym nie skrępowaną wolność społeczno-obyczajową. Obecnie brakuje wyrazistości treściowej w tym ruchu. Od kilku dekad można zauważyć siłę feminizmu radykalnego, który mocno wspierają ruchy i partie lewicowo-ateistyczne oraz niektóre środki masowego komunikowania (sympatyzujące $\mathrm{z}$ lewicą). Ich hasła koncentrują się na naciskach na władze państwowe, aby dopuściły aborcję na życzenie, powszechną antykoncepcję, eutanazję, wprowadziły do życia publicznego gender. Należy podkreślić, iż wiele tych kwestii coraz bardziej dzieli ruch kobiecy, w tym radykalny. Ten podział wynika $\mathrm{z}$ wielu zawiłych przemian życia społecznego i politycznego świata.

\section{WYDARZENIA ŚWIATOWE W OBLICZU FEMINIZMU I ABORCJONIZMU}

W ostatniej dekadzie na scenie politycznej zaszły dalekosiężne zmiany polityczne, które usuwają w cień ruchy socjaldemokratyczne, ateistyczne i liberalne. Aczkolwiek są one nadal bardzo silne, to jednak

${ }^{4}$ E. Machut-Mandecka, Kobieta bez zasłony. Muzułmanka, w świetle wiary i kultury, w: Być kobietą w Oriencie, red. D. Chmielowska, B. Grabowska, E. Machut-Mendecka, Warszawa 2008, s. 19-21.

5 Tamże, s. 21. 
ich znaczenie stale maleje. Natomiast w siłę rosną ruchy prawicowe, oparte na tradycyjnych wartościach chrześcijańskich i konserwatywnych. Coraz bardziej zauważalne są ruchy pro-life (za życiem). Wspierane są one przez wiele organizacji, instytucji, stowarzyszeń, zrzeszeń. Ważną rolę w tym względzie odgrywa Kościół oraz współdziałające z nim najróżniejsze stowarzyszenia, jak choćby Polskie Stowarzyszenie Obrońców Życia Człowieka, kierowane przez Antoniego Ziębę. Ruchy te organizują systematycznie: Marsze Dla Życia i Rodziny, Narodowe Dni Życia.

Obserwowane i ciągle trwające przemiany społeczno-polityczne w wielu krajach świata, przywracające szacunek dla życia poczętego, godność osobową każdego człowieka, wartości religijne i patriotyczne, dają nadzieję na trwałe zakorzenienie się podstawowych i fundamentalnych wartości aksjologicznych w życiu człowieka, czyli prawdę, dobro i piękno. Do najważniejszych przyczyn związanych z powyższymi przemianami można zaliczyć wiele szczegółowych kwestii, a w tym: bezsilność wielu państw wobec napływającej fali imigrantów; zmieniające się postawy wobec Unii Europejskiej; kult wolnego rynku, czyli neoliberalizm; pamięć o klęsce systemu komunistycznego w bloku państw Europy Środkowo-Wschodniej; nieudolność wielu rządów w kreowaniu polityki przyjaznej obywatelom; pojawiające się afery gospodarcze; pauperyzacja wielu społeczeństw; grzech aborcji.

Bardzo ważnym wydarzeniem na scenie politycznej Europy było zwycięstwo partii „Fidesz” (łac. wiarygodność) Viktora Orbana na Węgrzech (2010 i 2014 r.). Od tego momentu rozpoczęły się przemiany mentalności Europejczyków, trwające do dnia dzisiejszego. Warto przypomnieć, iż Tony Blair (socjaldemokrata), François Mitterand (socjalista), Jose Luis Rodrigues Zapatero (socjalista) - politycy, którzy jeszcze niedawno sprawowali rządy w najbardziej rozwiniętych państwach Europy, głosząc i uskuteczniając w prawodawstwach swoich krajów wartości ateistyczne i antyreligijne, odeszli z polityki, pozostawiając pustkę aksjologiczną, która jest powoli zapełniana innymi wartościami, które bardzo często odnoszą się do uniwersalnych wartości chrześcijańskich.

Ważnym wydarzeniem w zakresie omawianych treści było zwycięstwo polskiej prawicy w wyborach prezydenckich i parlamentarnych w 2015 roku. Pomimo zmasowanej krytyki kandydatów prawicy, do której włączyły się niemal wszystkie media (polskie i zagraniczne), zwycięstwo 
polskich konserwatystów było bardzo wyraźne i ważne z wielu punktów widzenia, zarówno dla Polski, jak i dla Europy i świata. Przejęcie władzy oznaczało porządkowanie wielu kwestii politycznych, gospodarczych, kulturowych. W Polsce rozpoczęła się odnowa moralna i patriotyczna. Aczkolwiek siły opozycyjne, wspierane przez wiele państw europejskich, ciągle atakują nasz nowy rząd i prezydenta, to jednak ta szczególna „nawałnica" nie odnosi większego skutku. W najtrudniejszych chwilach dla Polski wielu polityków udaje się na Jasną Górę - do Królowej Polski, prosząc o wsparcie, pomoc, siły do dalszej pracy. W tym miejscu warto przypomnieć historyczne już wydarzenie, jakim był Akt przyjęcia Jezusa Chrystusa za Króla i Pana (19 XI 2016 r.). Główne uroczystości odbyły się w sanktuarium w Łagiewnikach. Możemy ufać i mieć nadzieję, że Chrystus Król weźmie pod swoją opiekę nasz naród. Jednak Polacy muszą pamiętać o swoich chrześcijańskich korzeniach, o konieczności odnowy religijno-moralnej.

Ostatnim wydarzeniem o randze globalnej, a nawiązującym do podejmowanych treści, było zwycięstwo Donalda Trumpa w wyborach prezydenckich w Stanach Zjednoczonych (8 XI 2016 r.). D. Tramp to przedsiębiorca z Nowego Jorku, konserwatysta, chrześcijanin. Jego żona - Melania Trump - słoweńska modelka, chrześcijanka, odważnie głosi swoje religijne poglądy, również w dziedzinie ochrony życia poczętego. Jeszcze w czasie trwania kampanii wyborczej D. Trump wypowiadał się publicznie na temat wartości życia ludzkiego. Przed wyborami prezydenckimi zamierzał mianować takiego sędziego Sądu Najwyższego, który będzie przeciwko aborcji. Napisał też artykuł o swoim antyaborcyjnym stanowisku. Warto podkreślić, iż jego przeciwniczka w wyborach - Hilary Clinton - prezentowała stanowisko zgoła odmienne; popierała aborcję, eutanazję, homoseksualizm.

W tym czasie ruchy feministyczne w Stanach Zjednoczonych głośno i wyraźnie protestowały przeciwko konserwatywnej kandydaturze D. Trumpa. W sposób szczególny wyróżniał się feminizm radykalny, upatrując w tej kandydaturze ogromne, a wręcz śmiertelne zagrożenie. Feministki radykalne obawiały się, że po wyborach państwo zakaże aborcji, będą zamykane kliniki aborcyjne, państwo przestanie finansować wiele projektów niezgodnych z chrześcijańskim nauczaniem. W wielu miastach USA radykalne feministki organizowały marsze przeciwko nowemu prezy- 
dentowi („Marsze Kobiet”). W styczniu 2017 roku na ulice Waszyngtonu wyszło kilkaset tysięcy osób; marsz popierały inne miasta USA i świata.

W marcu 2013 roku, czwarty rok z rzędu, Peruwiańczycy wyszli na ulice Limy, by bronić prawa do życia wszystkich osób, od poczęcia aż do naturalnej śmierci. Organizatorzy IV Marszu dla Życia szacują, że wzięło w nim udział ponad 750 tysięcy osób. Obrońców życia wsparł sam kardynał Juan Luis Cipriano, arcybiskup Limy. Kapłan stwierdził, że marsz zgromadził największą liczbę obywateli, jaką kiedykolwiek udało się zebrać w historii Peru. Dodał, że „wszystkich zjednoczył jeden pomysł i jedna misja, aby bronić fundamentalnego prawa do życia”.

Podobna sytuacja miała miejsce w Polsce pod koniec sierpnia 2016 roku, kiedy do Sejmu wpłynęły dwa projekty w sprawie aborcji: zaostrzający prawo aborcyjne autorstwa "Stop Aborcji” oraz liberalizujący, wniesiony przez komitet „Ratujmy Kobiety”. Projekt proaborcyjny został odrzucony, wobec czego środowiska polskich radykalnych feministek, wsparte przez lewicowe i liberalne partie oraz sympatyzujące z nimi media, zorganizowały ogólnopolski protest: „Czarny Protest”, na którym zebrało się prawie 100 tys. osób. Największe demonstracje miały miejsce we Wrocławiu i w Warszawie. Niewielkie grupy zwolenników protestu demonstrowało w kilku krajach europejskich (Londyn, Sztokholm). Demonstracje zostały zauważone niemal przez wszystkie światowe media. W wyniku protestu odłożono prace nad tym projektem.

Protest mocno podzielił polskie społeczeństwo; na nowo odżyły dyskusje przeciwników i zwolenników aborcji. W tym czasie ukazało się wiele artykułów, prac i najróżniejszych wypowiedzi obu stron konfliktu. Można zauważyć, iż w sensie politycznym dla demonstrantów „Czarnego Protestu” był to sukces - w najbliższym czasie Sejm nie będzie pracował nad zaostrzeniem obecnej ustawy o ochronie życia poczętego. Natomiast dla obrońców życia był to prawdziwy dramat. Liczyli oni, iż nowa władza, nastawiona przychylenie do Kościoła, ograniczy aborcję. Stało się inaczej.

Analizując tę sytuację od strony Objawienia, daje się zauważyć wyraźne oznaki Bożej Opatrzności. Skala „Czarnego Protestu” była bardzo duża, stąd oddźwięk społeczny był również ogromny. W krótkim czasie

${ }^{6}$ Stolica Peru pro-life; http://www.pch24.pl/stolica-peru-pro-life--ponad-750tys--osob-na-marszu-dla-zycia-w-limie,41923,i.html [dostęp: 03.03.2017]. 
pojawiała się wielka liczba publikacji obrońców życia, które dokładnie omawiały to zagadnienie od strony medycznej, filozoficznej, teologicznej, kulturowej, społecznej i gospodarczej. Najwięcej informacji pojawiło się w Internecie, który w pewnym sensie jest „opanowany” prze ludzi młodych. Po raz pierwszy od wielu lat młodzi ludzie mogli zobaczyć, w jaki sposób przebiega spór pomiędzy „życiem a śmiercią” (zob. Pwt 30, 15-16). Mogli oni przekonać się naocznie, jak wygląda życie płodowe nienarodzonego człowieka, dzięki zamieszczanym filmom na forach internetowych. Śledząc uważnie komentarze, na plan pierwszy wysuwają się w sposób zdecydowany obrońcy życia. Rzadko można było spotkać opinie przeciwne. Był to swoistego rodzaju fenomen, którego owoce zapewne szybko poznamy. Można odnieść wrażenie, że Pan Bóg przygotowuje grunt pod nową ustawę broniącą życia poczętego. Jest to grunt zakorzeniany właśnie w tej grupie osób, które są najbardziej zainteresowane omawianymi kwestiami: aborcją, antykoncepcją, in vitro; zagadnienia te dotyczą przede wszystkich osób w wieku rozrodczym. Wydaje się, iż zmasowana edukacja, w którą włączają się media (szczególnie Internet) oraz Kościół, to fundament pod przyszłe zmiany ustawy o ochronie życia poczętego.

Warto wrócić do wyboru D. Trumpa na prezydenta najpotężniejszego państwa świata. Przed jego mianowaniem w USA wykonano ogromną ilość aborcji. Jak podaje "Gość Niedzielny", do czasu legalizacji aborcji w Stanach Zjednoczonych, wykonano ponad 57 mln zabiegów; dane te są przerażające. Obecnie w USA morduje się pond milion bezbronnych, nienarodzonych dzieci rocznie ${ }^{7}$. Tymczasem D. Trump już w pierwszych dniach swojego urzędowania poczynił kroki mające na celu ograniczenie promocji aborcji. Prezydent podpisał dekret, który blokuje zagraniczną pomoc lub finansowanie $\mathrm{z}$ budżetu federalnego międzynarodowych organizacji pozarządowych, które mają na celu promocje aborcji. Zgodnie z nowym dekretem prezydenta Donalda Trumpa, organizacje pozarządowe, które w ramach swojej działalności oferują lub promują aborcję, będą pozbawione jakiegokolwiek finansowania ze strony Amerykańskiej Agencji Rozwoju Międzynarodowego. Ciekawostką jest fakt, iż dekret został podpisany zaledwie dwa dni po słynnym „Marszu Kobiet”, który zorganizowały środowiska lewicowe, w tym radykalne feministki.

7 Przerażajacy bilans aborcji w USA, „Gość Niedzielny” 17 (2017), s. 12. 
Warto przypomnieć, że jeszcze w kampanii prezydenckiej Donald Trump podkreślał, że jeśli zwycięży w wyborach to jako członka Sądu Najwyższego wybierze sędziego, którego poglądy będzie można określić mianem "pro-life”. Ostatecznie Neil Gorsuch został nominowany przez Donalda Trumpa na dożywotnią funkcję sędziego Sądu Najwyższego. Prezydent-elekt Donald Trump do swojej przejściowej administracji powołał republikańską polityk pro-life, Cathy McMorris Rodgers na stanowisko sekretarz spraw wewnętrznych. Oznacza to, że prezydent Trump wyraźnie uderza w proaborcyjną organizację Planned Parenthood. Można zauważyć iż nowa władza będzie mniej tolerancyjna dla zabijania nienarodzonych i przemysłu aborcyjnego, niż politycy skupieni wokół B. Obamy.

Kolejny, bardzo ważny fakt, to powołanie przez prezydenta D. Trumpa nowej ambasador przy ONZ - Nikki Haley. Warto podkreślić, że N. Haley wielokrotnie wspierała ruchy pro-life, a także opowiadała się za zakazem aborcji. Wypowiedziała także wojnę nieetycznym praktykom proaborcyjnej organizacji Planned Parenthood. Nowa ambasador powiedziała: „Wierzę, że każde życie ma wartość i jest błogosławieństwem od Boga. (...) Mam nadzieję, że nadal będziemy wspólnie wspierać i działać

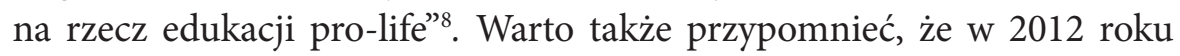
Haley podpisała m.in. Born-Alive Infant Protection Act, pozwalający na zwiększenie ochrony życia. Dokument dotyczył sytuacji prawnej dzieci, które przeżyły aborcję i urodziły się żywe. Dzięki prawu podpisanemu przez Nikki Haley, dzieci urodzone wskutek nieudanej aborcji nie mogły być traktowane jako „odpady medyczne” lub umyślnie zabijane9.

Omawiając wydarzenia światowe w obliczu feminizmu i aborcjonizmu, warto podkreślić, iż od kilku lat na terenie całej Unii Europejskiej daje się zauważyć zwrot w kierunku konserwatyzmu oraz odchodzenie od lewicy i liberalizmu. Wielu komentatorów życia publicznego podkreśla, iż „skręt w prawo” będzie się w Europie pogłębiał. Skrajnie prawicowy Front Narodowy odniósł spektakularne zwycięstwo w pierwszej turze wyborów regionalnych we Francji, natomiast Partia Socjalistyczna zajęło dopiero

8 Wspierała ruchy pro-life w USA; http://www.pch24.pl/wspierala-ruchy-prolife-w-usa--donald-trump-mianuje-ja-ambasadorem-przy-onz,47602,i.html [dostęp: 02.03.2017].

9 Tamże. 
trzecie miejsce; wybory parlamentarne we Francji odbędą się w grudniu 2017 roku. W tym samym roku wybory odbędą się w Niemczech i Austrii.

Obecnie w Europie można zauważyć coraz większą sympatię do wartości narodowych, patriotycznych, chrześcijańskich i antylewicowych. Media informują, iż w Europie przychylne prawicy są państwa: Polska, Węgry, Bułgaria, Łotwa, Hiszpania, Anglia i Irlandia. Natomiast Niemcy, Finlandia, Luksemburg, Cypr i Belgia uważane są za „państwa centrum”; $\mathrm{w}$ pozostałych większość sympatyzuje z lewicą. W ostatnich dniach media informują, że prawica zdobywa coraz silniejszą pozycję także w Austrii, Francji, Wielkiej Brytanii, Włoszech czy nawet w Niemczech. Niemniej jednak obecnie w Europie sytuacja $\mathrm{w}$ tym względzie jest bardzo dynamiczna i trudna do jednoznacznego określenia. Wystarczy jakiś dramat, np. atak terrorystyczny na większą skalę, a zaprezentowany powyżej obraz może ulec szybkiej i radykalnej zmianie.

Na tym tle można dokładnie prześledzić ruchy lewicowe, w tym feminizm radykalny, który nie może sobie poradzić ze swoją tożsamością. Na dzień dzisiejszy brakuje wyrazistych liderów tego ruchu, którzy byliby rozpoznawalni, otaczaniu szacunkiem, estymą. Wydaje się, że feminizm radykalny staje się ruchem, który popierają wyłącznie osoby skrajnie lewicowe lub te, które wyznają wartości ateistyczne.

\section{ARGUMENTY FEMINISTEK RADYKALNYCH I OBROŃCÓW ŻYCIA}

Feminizm radykalny jest skrajnym odłamem feminizmu. $\mathrm{W}$ założeniach tego ruchu jest likwidacja patriarchatu, który uciska kobiety, marginalizując je, prowadzi do rasizmu. Feministki radykalne uważają, że patriarchat prowadzi do molestowania seksualnego, gwałtów, prostytucji. Kobiety traktowane przedmiotowo, chorują na anoreksję czy bulimię. Feminizm radykalny dąży do wprowadzenia aborcji bez żadnych ograniczeń, zalegalizowania homoseksualizmu, antykoncepcji, propagowania współżycia nawet wśród dzieci, wprowadzenia do szkół szkodliwych elementów wychowania seksualnego. Ponadto promowanie genderyzmu, in vitro, eksperymentów medycznych na ludzkich zarodkach. Poglądy feminizmu radykalnego zawierają $w$ swoich treściach pozytywne przesłania, jak choćby problem dyskryminacji ze względu na płeć, zagadnienia związane 
z molestowaniem, gwałtami, pornografią, koniecznością poprawy systemu opieki nad dziećmi, itp. Jednak argumenty związane z szeroko pojmowaną obyczajowością, są nie do przyjęcia dla większości obywateli, a szczególnie tych, którzy zostali ukształtowani przez cywilizację chrześcijańską.

Europejska lewica oraz feminizm radykalny są obecnie bardzo zaniepokojone opisanymi powyżej wydarzeniami, które osiągają skalę globalną. Po wygranych wyborach na Węgrzech, w Polsce i w USA, w siłę rosną ruchy pro-life. Tak zwane „Czarne Marsze” w Polsce i w Stanach Zjednoczonych, odrzucenie przez polski Sejm ustawy zaostrzającej aborcję, stały się niejako stymulatorami dla obrońców życia, którzy cyklicznie organizują (w całej Europie), Marsze dla Życia. Wystarczy wspomnieć demonstracje pro-life w Polsce, które gromadzą coraz większą rzeszę sympatyków, w tym ludzi młodych, małżeństw. Słoweńcy w 2015 roku odrzucili w referendum propozycję małżeństw jednopłciowych; Litwini zakazali prowadzenia indoktrynacji homoseksualnej wobec dzieci; Francuzi demonstrują przeciwko instytucjonalizacji związków jednopłciowych. W lutym 2017 roku w Parlamencie Europejskim pod patronatem proaborcyjnej kampanii odbyła się konferencja, podczas której działaczki feministyczne dały wyraz frustracji z powodu rosnącego poparcia dla ochrony życia i rodziny.

Sukces Europejskiej Inicjatywy Europejskiej „Jeden z Nas” (One of Us) skłonił środowiska feministyczne i proaborcyjne do uruchomienia kampanii All of US zrzeszającej lewicowych europosłów z Grupy Zielonych, ALDE, S\&D, GUE/NGL. Organizowana w ramach tej kampanii konferencja „My Body My Rights” miała na celu mobilizację młodych ludzi do walki o „prawa i zdrowie seksualne i reprodukcyjne”, czyli nieskrępowany dostęp do antykoncepcji i możliwości zabijania dzieci w łonach matek. Uczestnikami wydarzenia byli członkowie partii politycznych i organizacji pozarządowych z państw UE (m.in. z Chorwacji, Wielkiej Brytanii, Hiszpanii i Polski) ${ }^{10}$. Feministki radykalne podczas kampanii All of US wyraziły głębokie zaniepokojenie, iż ruchy pro-life rosną w siłę (na całym świecie), a aborcjoniści napotykają coraz większe przeszkody.

${ }^{10}$ Feministki nie kryja frustracji z powodu rosnącej sity ruchów pro-life; „Ordo Iuris" (13.02.2017). 
Środowiska feministyczne i proaborcyjne otwarcie wymieniają inicjatywy coraz liczniejszych środowisk chroniących życie ludzkie; w sposób szczególny akcentują obywatelski projekt „Stop Aborcji” w Polsce oraz organizowane niemal w całej Europie „Marsze dla Życia”. Duże obawy i niepewność wśród europejskich ruchów lewicowych budzi także niedawny wybór nowego przewodniczącego Parlamentu Europejskiego, Włocha Antonio Tajaniego, który zapowiedział walkę z powszechnym dostępem do tzw. aborcji. Niektóre europosłanki zapowiedziały, że będą wywierać presję na Tajaniego, aby zmienił swój stosunek do zabijania nienarodzonych. Chcą też naciskać na Komisję Europejską, aby ta forsowała w państwach członkowskich ratyfikację tzw. Konwencji Stambulskiej (CAHVIO) oraz powszechne udostępnienie aborcji, mimo że (jak przyznała europejska Komisarz ds. Równości Vera Jurova), nie leży to w zakresie kompetencji UE. Ruchy na rzecz ochrony życia i rodziny swoją determinacją, skutecznością i rosnącym profesjonalizmem sprawiają, że lewicowe programy tracą wiarygodność, a ich propagatorzy doświadczają frustracji ${ }^{11}$.

Siłę ruchów pro-life można było zauważyć w czasie „Marszu dla Życia” w Waszyngtonie (22 styczeń 2017 r.), który zgromadził ponad 300 tys. uczestników. Większość demonstrujących to katolicy ${ }^{12}$. Znamiennym był fakt, iż po raz pierwszy w dziejach Stanów Zjednoczonych w marszu dla życia udział wziął wiceprezydent M. Pence (chrześcijanin). Marsz dla Życia odbywał się w wyjątkowej atmosferze. Tydzień wcześniej te same ulice amerykańskiej stolicy wypełnili uczestnicy uroczystości inauguracyjnych prezydenta Donalda Trumpa. A dzień później wyszli na nie zwolennicy aborcji uczestnicząc w tzw. „Marszu Kobiet”. Wiceprezydent powiedział: „Życie znów wygrywa w Ameryce. Społeczeństwo może być oceniane na podstawie tego, jak dba o najsłabszych, o ludzi starszych, niedołężnych i niepełnosprawnych oraz o tych jeszcze nienarodzonych"13. Waszyngtoński Marsz poprzedzony został Eucharystią odprawioną w bazylice Narodowego Sanktuarium Niepokalanego Poczęcia, którą sprawował kard. T. Dolan z Nowego Jorku. Warto podkreślić, iż przed Marszem Amerykanie modlili się przez 9 dni nowenną w intencji szacunku dla życia.

\footnotetext{
11 Tamże.

${ }^{12}$ W USA do katolicyzmu przyznaje się ponad 20\% społeczeństwa.

13 Katolicka Agencja Informacyjna, 27 I 2017 r.
} 
W ostatnich latach obrońcy życia podejmują szereg inicjatyw, które zmierzają do ochrony nienarodzonych. Ich działalność polegająca na organizowaniu demonstracji, edukacji poprzez wszystkie media, organizowaniu kampanii społecznych (np. bilbordy), naciskaniu na parlamenty państw oraz na wytrwałej modlitwie, odnoszą coraz wyraźniejsze skutki. Dostrzega się przemianę mentalności wielu ludzi, a szczególnie tych niezdecydowanych, którzy przyłączają się do obrońców życia. Na świecie zamyka się kliniki aborcyjne, coraz więcej lekarzy odmawia wykonania aborcji ze względu na klauzulę sumienia, wystarczy wspomnieć polskiego ginekologa prof. Bogdana Chazana, zwolnionego z pracy. Podobna sytuacja spotkała polską lekarkę pracującą w Norwegii - Krystynę Jachimowicz. W Stanach Zjednoczonych maleje też liczba lekarzy chętnych do zabijania nienarodzonych dzieci. Młodzi medycy nie garną się do tego zajęcia, natomiast starsi, zajmujący się dotąd tym zbrodniczym procederem, powoli przechodzą na emeryturę. Spadek ilości aborcji wykonywanych w USA wynika także negatywnego nastawienia kobiet do takiej praktyki ${ }^{14}$.

Zarysowane powyżej wydarzenia w skali globalnej pokazują, że ruch obrońców życia odnosi coraz bardziej widoczne sukcesy. Dane statystyczne z wielu krajów świata (np. USA), pokazują, że liczba aborcji spada. Aktywiści aborcyjni, dotąd bardzo skuteczni i aktywni, są coraz starsi, powoli odchodzą z zawodu. Natomiast młodzi lekarze nie są skłonni zabijać nienarodzone dzieci, gdyż często wiąże się to z piętnem dzieciobójstwa. Aborcja coraz powszechniej budzi zniesmaczenie szerokiej opinii publicznej.

Patrząc na to zagadnienie od strony Objawienia, daje się zauważyć wyraźną Bożą pomoc dla obrońców życia, dla poszanowania każdej istoty ludzkiej. Fakt ten należy bezwzględnie wiązać z przemianą mentalną moralną, etyczną, religijną, kulturową - coraz większych mas społecznych na świecie. Bez nawrócenia, przemiany życia, umiłowania bliźnich, wyzbycia się grzechu, nie będzie skutecznej Bożej pomocy w omawianym względzie. Kościół poprzez swoich kapłanów nieustanie przypomina o świętości życia, uczy, że Słowo Boże jest żywą siłą, zdolną do nawróce-

14 Trwa ofensywa pro-life w USA; http://www.pch24.pl/trwa-ofensywa-prolife-w-stanach-zjednoczonych---gwaltownie-spada-liczba-aborcji,33769,i.html [dostęp: 02.03.2017]. 
nia ludzkiego serca i do ponownego ukierunkowania człowieka ku Bogu (Papież Franciszek, orędzie na Wielki Post, 22 X 2016).

Niezmiernie ważną kwestią dotyczącą obserwowanych przemian politycznych, społecznych i religijnych, jest pokuta i post (zob. Jl 2,11). Dzieła te podsiadają w sobie ogromną moc, a w połączeniu z przemianą serc, modlitwą, mogą wyprosić u Pana łaskę powszechnego zrozumienia cudu i piękna życia ludzkiego. Obserwowane dotąd ruchy feminizmu radykalnego ulegną zatarciu, zniszczeniu, a przynajmniej w najbardziej dyskusyjnych przejawach, wiążących się z niszczeniem życia ludzkiego. Można założyć, iż w najbliższych latach, dekadach, schyłek tych ruchów uwolni jeszcze bardziej świadomość społeczną u szerszej masy ludzkości opowiadające się „pro-life” - za życiem.

\section{PODSUMOWANIE}

Początki feminizmu w pierwszym etapie były jasne, przejrzyste i wyraźnie skrystalizowane co do celu, intencji, misji, jak i ideałów. Panie chciały, aby zostały zrównane prawa cywilne z mężczyznami (emancypacja intelektualna). Ważną kwestią było zrównanie praw politycznych mężczyzn i kobiet (prawa wyborcze).

Druga fala feminizmu dążyła do zrównania płci, znosząc nawet różnice biologiczne, tworząc nowe struktury społeczne, oparte na zniesieniu ról mężczyzny i kobiety (antyseksizm). Ponadto walczono o prawo do aborcji. Ważnym zagadnieniem była walka o równouprawnienie na szeroko pojmowanym rynku pracy. Drugi etap feminizmu zrodził się $\mathrm{z}$ rozczarowania dotychczasowymi staraniami na rzecz równouprawnienia.

Trzecia fala stanowi mało precyzyjny ruch kobiet, który nie posiada jasno wyklarowanej wizji. Istniejące współcześnie różne przejawy i poglądy feministyczne akcentują wiele problemów, z których na plan pierwszy wysuwają się zagadnienia związane z płciowością, rodziną, wizją kobiety wyzwolonej od wszystkiego, nawet od własnej biologii.

Radykalny feminizm wyklucza naturę; człowiek może sam wybierać sobie płeć fenotypową, zmodyfikowaną. Podejmowanie kwestii aborcji, antykoncepcji, w pewnym stopniu skłóca ruch feministyczny, gdyż bardziej ugodowe odłamy nie godzą się z taką perspektywą. Sporym 
problemem jest wejście feministek na grunt teologii i religii. Feministki tworzą własną religię, ustalają własne doktryny religijne. Wizja kobiet $\mathrm{w}$ radykalnych ruchach feministycznych stanowi zagrożenie dla funkcjonowania tradycyjnych rodzin, dla małżeństwa, rodzicielstwa i szeroko pojmowanej miłości małżeńskiej i rodzicielskiej.

Wydarzenia społeczno-polityczne ostatnich lat pokazują, iż feminizm radykalny, promujący między innymi aborcję, antykoncepcję, eutanazję, in vitro, związki homoseksualne, seksualizację dzieci, wchodzi w okres schyłkowy. Wymiana elit rządzących na Węgrzech, w Polsce i w Stanach Zjednoczonych stała się silnym bodźcem dla ruchów pro-life, które rosną w siłę, uświadamiają całe społeczeństwa co do wartości życia ludzkiego oraz zbrodni aborcji. Można założyć, iż tymi globalnymi ruchami steruje Pan Bóg, pochylając się nad grzeszną ludzkością. Wylana dotąd niewinna krew dzieci nienarodzonych, staje się jakby nowym posiewem dla chrześcijaństwa.

Streszczenie. Termin „feminizm” to ideologia, ruch społeczno-polityczny propagujący emancypację, równouprawnienie, przeciwdziałanie dyskryminacji, zwiększenie udziału kobiet w życiu publicznym. Ponadto promuje on kobiecość oraz płeć kulturową, związaną z genderyzmem. W sposób szczególny wyróżnia się obecnie feminizm liberalny, socjalistyczny i radykalny, aczkolwiek istnieje spora liczba innych jego odmian. Warto podkreślić, iż Kościół propaguje tak zwany „nowy feminizm”, oparty na Objawieniu.

Współcześnie na plan pierwszy wysuwa się feminizm radykalny, który wspierają lewicowi dziennikarze, stąd jest on najbardziej rozpoznawalny, krzykliwy, emocjonalny. Feminizm radykalny podejmuje szereg zagadnień związanych z życiem kobiet w XXI wieku, koncentrując się przede wszystkim na likwidacji patriarchatu, uskutecznianiu niczym nie skrępowanej wolności, np. w zakresie płciowości, obyczajowości. Feministki walczą ponadto z wieloma założeniami Kościoła, np. z zakazem aborcji, antykoncepcji, eutanazji, in vitro.

W niniejszym artykule ukazany zostanie feminizm radykalny, który wydaje się być $\mathrm{w}$ fazie schyłkowej, na tle dynamicznych zmian społeczno-politycznych świata. W siłę rosną ruchy obrońców życia, wspierane przez konserwatystów Europy, USA i innych krajów. W tych zmianach daje się zauważyć wyraźny plan Stwórcy, który pragnie ratować grzeszny świat, pragnie ratować i zbawić każdego człowieka.

Słowa kluczowe: feminizm; patriarchat; konserwatyzm; ruch pro-life.

Abstract. The end of radical feminism - the rise of the signification of pro-life movements in the context of the contemporary international situation. The term 
"feminism" is an ideology, a socio-political movement promoting emancipation, equality, counteracting discrimination, increasing women's participation in public life. In addition, it promotes femininity and cultural sex, which is connected to gender. In particular way, liberal, socialist and radical feminism are able to be pointed out. Although there are a number of other variants. It is worth emphasizing that the Church promotes so-called "new feminism," based on Revelation.

Nowadays radical feminism has come to the bottom line. It is supported by left-wing journalists, hence it is the most recognizable, lurid and emotional movement. Radical feminism addresses a number of issues related to the lives of the women in the 21 st century, focusing primarily on the abolition of the patriarchate, promoting unconstrained freedom, in the context of sexuality and customs. Feminists also struggle with many Church assumptions, such as the ban on abortion, contraception, euthanasia, and in vitro.

In the following article radical feminism is presented. The ideology seems to be in the decline phase, in the context of dynamic socio-political changes in the world. The movements of life defenders, supported by conservatives from Europe, USA and other countries, are growing in strength. In these changes can be seen a clear plan of the Creator, who wants to save the sinful world and save every human being.

Key words: feminism; patriarchy; conservatism; pro-life movement.

\section{BIBLIOGRAFIA}

Feministki nie kryją frustracji $z$ powodu rosnącej siły ruchów pro-life; "Ordo Iuris” (13.02.2017).

Machut-Mandecka, E., Kobieta bez zasłony. Muzułmanka w świetle wiary i kultury w: Być kobieta w Oriencie, red. D. Chmielowska, B. Grabowska, E. Machut-Mendecka, Warszawa 2008, s. 19-21.

Mroczkowska, J.P., Nowy feminizm amerykański, „Znak” 8 (1995), s. 97.

Przerażający bilans aborcji w USA, „Gość Niedzielny” 17 (2017). s. 12.

Stolica Peru pro-life; http://www.pch24.pl/stolica-peru-pro-life--ponad-750-tys--osob-namarszu-dla-zycia-w-limie,41923,i.html [dostęp:03.03.2017]

Titkow, A., Feminizm, w: Encyklopedia socjologii, Z. Bokszański (red.), Warszawa 1998.

Trwa ofensywa pro-life w USA; http://www.pch24.pl/trwa-ofensywa-pro-life-w-stanachzjednoczonych---gwaltownie-spada-liczba-aborcji,33769,i.html [dostęp: 02.03.2017].

Wiśniewska-Roszkowska, K., Feminizm zreformowany, Wrocław 1993.

Wspierała ruchy pro-life $w$ USA; http://www.pch24.pl/wspierala-ruchy-pro-life-wusa--donald-trump-mianuje-ja-ambasadorem-przy-onz,47602,i.html [dostęp: 02.03.2017] 